\title{
EFFECT OF EFFLUENT WATER ON POPULATION DYNAMICS OF COWPEA APHID, APHIS CRACCIVORA KOCH (HEMIPTERA: APHIDIDAE), ON COWPEA PLANTS
}

\author{
TIROESELE B. ${ }^{*}$, NKETSO T.H. AND TSHWENYANE S.O.
}

Department of Crop Science and Production, Botswana College of Agriculture, Private Bag 0027, Gaborone, Botswana. *Corresponding Author: Email- btiroese@yahoo.com

\author{
Received: August 01, 2013; Accepted: August 29, 2013
}

\begin{abstract}
Cowpea, Vigna unguiculata (L.) is an important legume grown in Botswana and the main yield losses incurred are from cowpea aphid, Aphis craccivora (Koch). Agriculture in Botswana is hampered by limitation in water resources. The objective of this study was to determine the effect of effluent water on cowpea aphid reproduction and population growth. This was randomized completely block design pot experiment conducted under net shade environment. Four treatments of $100 \%, 60 \%, 30 \%$ of effluent dilution and the control being clean tap water were used. This study revealed that the presence of $\mathrm{N}$ and $\mathrm{K}$ in the effluent water did not affect the population growth of aphids on cowpea plants. There was no significant difference among the effluent water treatments and the clean tap water. Therefore, effluent water in this study did not show any effect on cowpea aphid reproduction and population growth.
\end{abstract}

Keywords- Aphis crassivora, cowpea plant, effluent water

Citation: Tiroesele B., Nketso T.H. and Tshwenyane S.O. (2013) Effect of Effluent Water on Population Dynamics of Cowpea Aphid, Aphis Craccivora Koch (Hemiptera: Aphididae), On Cowpea Plants. International Journal of Agriculture Sciences, ISSN: 0975-3710 \& E-ISSN: 09759107, Volume 5, Issue 2, pp.-363-366.

Copyright: Copyright@2013 Tiroesele B., et al. This is an open-access article distributed under the terms of the Creative Commons Attribution License, which permits unrestricted use, distribution and reproduction in any medium, provided the original author and source are credited.

\section{Introduction}

Today's agriculture is faced with a problem of decreasing availability for irrigation water since there is ever increasing competition for use of water in agriculture, manufacturing and industries. This competition has led to use of water of marginal quality for irrigation [1]. Sewage waste water is the component of domestic waste comprising bathroom and laundry effluents (grey water) and sewage waste (black water). Generally this wastewater is processed through waste water treatment plants to produce a definable quality of sewage wastewater that may be recycled for a range of purposes. The beneficial use of treated effluents for agriculture is the major reuse application worldwide. Currently, most countries still have no legal framework for wastewater reuse in agriculture. Effluent contains valuable resources, such as nutrients and organic matter, however, it also can contain concentrations of chemical contaminants, salts and pathogens that are potentially detrimental to soils or plant growth. Nutrients in effluent such as phosphorus, magnesium, nitrogen, sulfur, potassium and calcium are generally beneficial to plant growth [2].

Development of agriculture in Botswana is especially hampered by a number of challenges, the most significant of which is limitation in water resources. Botswana is an arid to semi-arid country and it receives little rainfall ranging from a high of 550 and low of $200 \mathrm{~mm}$ per year with an estimated annual average evaporation rate of 1400 $\mathrm{mm}$. It is a water stressed country and with lack or little water harvesting strategies, the country has turned to the use of effluent water to meet demands of water for irrigation. Notwane river, in the capital city Gaborone, receives treated sewage water discharged from wastewater treatment plant in Gaborone. This water is used by farmers to water their vegetables and other crops because of the scarcity of water in the country and also because of its nutritive advantage. Some of the crops are attacked by insects. Whether the water nutritive quality may have any impact on insect abundance is not fully understood. Over the past decade, the once overwhelmingly forest area around the river has been gradually replaced by agricultural community mainly because of easy access and cheap water. With these developments especially along the Notwane River, the threat of pests appears ever greater than in the past. It is well documented that agricultural operations play a significant role in the production of pest around the world [3].

Cowpea, Vigna unguiculata (L.) Walp. (Fabaceae), is a widely cultivated and the third most important crop in Botswana after maize, Zea mays L., and grain sorghum, Sorghum bicolor (L.) Moench (both Poaceae). It is an annual legume crop that is eaten in the form of dry seeds, green pods, green seeds and tender green leaves, and also utilized for fodder under a wide range of conditions [4]. Cowpeas play a critical role in the lives of millions of people in Africa and other parts of the developing world. It is of nutritional importance because it is high in protein content, therefore it can be a good replacement for beef, chicken and fish. The cowpea grains and leaves have a high protein content of about $24.8 \%$, fat content of $1.9 \%$, fiber content of $6.3 \%$, carbohydrate content of $6.3 \%$ and water content of $8-9 \%$ [5]. The crop is also a valuable and dependable commodity that produces income for many small holder farmers and traders in Sub-Saharan Africa [6].

One of the major biological constraints in cowpea production is their 
infestation and damage by various pests in the field and during storage [7]. Yield losses caused by field pests have been reported to range from 20 to $100 \%[8,9]$. The cowpea aphid, Aphis craccivora Koch (Hemiptera: Aphididae), is one of the major insect pests of cowpea. This insect is considered an important field pest of cowpea in Africa, Asia and Latin America [10]. Its high infestation can result in stunted plants, abscission of pods and shriveled seed [11], with a yield loss of up to $50 \%$ in Botswana [9].

Effluent water has been reported to have nutrients such as phosphorus, nitrogen, potassium, iron, calcium, magnesium and zinc. It is, therefore, suspected to have high nutritional value to crop production because of its mineral composition $[1,12]$. Some of these nutrients present in the water have been reported to have positive effect and others have negative effect on aphid population growth. Effluent water is suspected to be capable of boosting insect reproduction due to its nutrient composition such as nitrogen $[13,14]$. Nitrogen has been reported to be capable of increasing the reproduction of aphids [15-17]. In contrary, the increased levels of potassium have been found to reduce the aphid populations [18-20]. There is no research work that has been done on the effect of effluent water on population growth of aphid. Therefore, this work is meant to establish the relationship between effluent water and aphid population growth. This information might be useful for decision making in integrated pest management.

\section{Materials and Methods \\ Experimental Design and Layout}

The experimental site was at Botswana College of Agriculture gardens under net shade conditions. Four similar net-shades were used for this experiment. Cowpea plants (ER7) were planted to evaluate the effect of effluent water on cowpea aphid population growth. The plants were sown in polythene plastic pot containing garden soil. Two seeds were sown per hole at the depth of $5 \mathrm{~cm}$ and were later thinned to one after emergence by choosing a healthy looking seedling. Seeds which failed to emerge were replanted three days after emergence. No insecticide or fertilizer was applied on the experimental plants. Nets shades were kept free from weeds by regular manual weeding throughout the 5 weeks of the study period.

The pots of the cowpea plants were arranged in a randomized completely block design. Four water treatments viz treatment $1(100 \%$ effluent water $+0 \%$ tap water), treatment $2(60 \%$ effluent water + $40 \%$ tap water), treatment 3 (40\% effluent water $+60 \%$ tap water) and treatment $4(0 \%$ effluent $+100 \%$ tap water) were used in the experiment and were replicated four times ending with a total number of thirty two experimental plants. One replicate consisted of eight potted plants for each treatment in each of the four net-shade houses. The pots were randomly placed in the net shade house. Effluent water which was used to irrigate the cowpea plants was collected from Notwane river. The water was sent to National Environmental Laboratory at the Department of Waste Management and Pollution Control for various quality parameters (analysis of nutrients and their concentrations levels).

\section{Aphid Colony}

The cowpea aphid colony used for this study was obtained from a net-shade culture reared from progeny of a single apterous female. The aphid was maintained on susceptible cowpea plants inside proof cages. To avoid crowding, aphids were continuously transferred to new plants until the start of the experiment.

\section{Experimental Conditions}

The experiment was started when aphid colony had enough nymphs to infest all the experimental cowpea plants. A camel's hair brush was used to individually place neonate nymphs on individual cowpea plants. These nymphs were approximately same age and weight. Each nymph was examined daily to record the time length from the onset of reproduction also known as pre-reproductive period. The number of progeny per adult was recorded daily for the duration of the experimental period.

\section{Data Collection}

The cowpea aphid counts per plant started to be taken from 3 days after inoculation with cowpea aphids up to the end of the experiment (five weeks). Sampling was done between 900 and $1200 \mathrm{~h}$. The cowpea developmental stages were recorded on each sampling date. The cowpea vegetative V1: first node, V2: second node, V3: third node, and $V(n)$ represent $n$ number of nodes on the main stem with fully developed leaves) and reproductive growth stages (R1: beginning bloom, R2: full bloom, R3: beginning pod, R4: full pod, R5: beginning seed, and R6: full seed stage, respectively) were identified according to Fehr [21]. Data collection was done by in-situ observation (visual counts on the plant) of insects on the plant. The cowpea aphid numbers were determined by counting those present on five randomly selected plants per replicate for all the treatments. Counts were taken from the top five trifoliate leaves.

\section{Data Analysis}

All data were subjected to analysis of variance (ANOVA) using mixed model procedures (PROC MIXED IN SAS [22]). Multiple comparisons were made on least square means. Differences among treatment means were based on LSD and considered significant when $P \leq 0.05$.

\section{Results and Discussion \\ Aphid Population Growth Pattern}

The experiment was conducted for 32 days after inoculating cowpea plants with cowpea aphids. The [Fig-1] depicts the aphid population dynamics from day 4 of observation to the last day of observation for all the treatments.

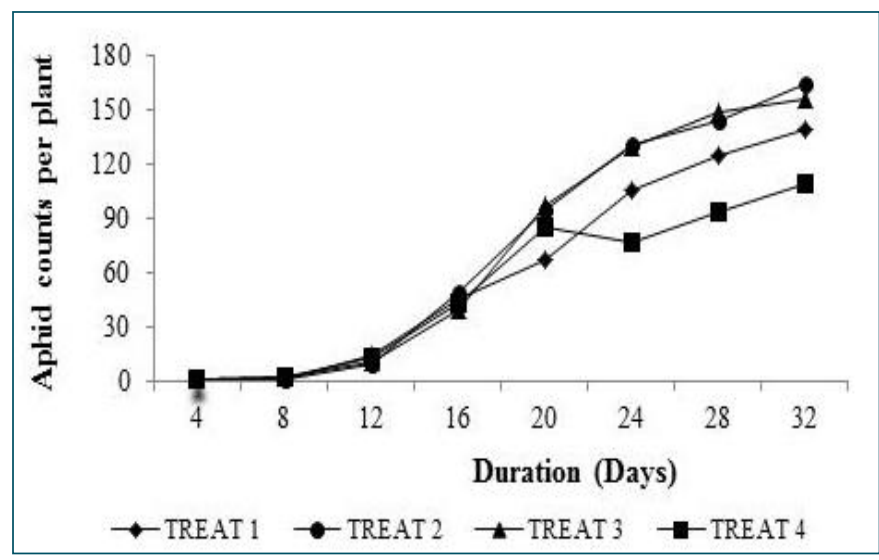

Fig. 1- Population Dynamics of Cowpea Aphid among the Treatments

There was no significant growth of aphid population from Day 4 to Day 12 for all the treatments. The aphid population started to increase after day 12 of observation for all treatments and still showed an increase trend at the last day of observation. Aphids have a tremendous capacity for reproduction and increase in popu- 
lation. Karley, et al [23] reported that aphids can double a population in just 3 days.

\section{Comparison of Average Number of Aphids per Plant among the Treatments}

The average population of cowpea aphids per plant from the first day of observation to last day of observation among all treatments (control inclusive) was found not to be significantly different $\left(F_{3,1462}\right.$ $=20.19 ; \mathrm{P}<0.8983$ ) [Table-1]. The results of this study have shown that effluent water does not have impact on aphid population growth as this was evident when comparing with clean tap water as observed in [Table-1]. Effluent water has been reported to have relatively high nitrate contents $(35.5 \mathrm{mg} / \mathrm{l})$ [Table-4]. Therefore, this water was expected to increase the population growth of aphids in our experiment. This is because nitrogen has been reported to have a positive correlation with aphid growth [24]. Nitrogen is essential in insect development, aphids inclusive by increasing the abundance of free amino acids in the plant [25]. The aphid infestation per plant showed significant difference among the four treatments, control inclusive, at each day of observation $\left(F_{7,86}=11.79\right.$; $\left.P<0.0001\right)$ [Table-2]. When looking at particular days chosen at random throughout the observation period, it was observed that treatments were significantly different in aphid infestation only at day $8\left(\mathrm{~F}_{3,8}=\right.$ $0.75 ; \mathrm{P}<0.0001)$ [Table-2] where treatment 3 had significantly higher aphid infestation than other treatments. Treatment 1 and 4 were not significantly different in aphid infestation per plant after day 8 . In addition, other treatments also did not show any significant difference in aphid infestation up to day 32 [Table-2]. However, from day 24 to day 32, there was least population growth on the control as compared to other treatment levels.

Table 1- Average Number of aphids per plant in all the treatments throughout the experimental period

\begin{tabular}{|lc|}
\hline Treatment & Mean \pm SE \\
1 & $2.808 \pm 1.331^{\mathrm{a}}$ \\
2 & $3.754 \pm 0.394^{\mathrm{a}}$ \\
3 & $3.490 \pm 0.397^{\mathrm{a}}$ \\
4 & $3.454 \pm 1.331^{\mathrm{a}}$ \\
\hline
\end{tabular}

*Means within a column followed by the same small letter are not significantly different $(P \leq 0.05)$.

${ }^{*}$ Treat 1 is $100 \%$ sewage water, treat 2 is $60 \%$ sewage water, treat 3 is $30 \%$ sewage water, and treat 4 is control (Clean tap water). Dilution was done with clean tap water.

Table 2- The number of Aphids per plant after Infestation at a 4 day interval among the treatments

\begin{tabular}{|lcccccccc|}
\hline \multicolumn{1}{c}{ Observation Day } \\
Treatment & 4 & $\mathbf{8}$ & 12 & 16 & 20 & 24 & 28 & 32 \\
\hline 1 & $1^{\mathrm{a}}$ & $1.25^{\mathrm{bc}}$ & $13.83^{\mathrm{a}}$ & $16^{\mathrm{a}}$ & $67.17^{\mathrm{a}}$ & $105.33^{\mathrm{a}}$ & $123.83^{\mathrm{a}}$ & $139.08^{\mathrm{a}}$ \\
2 & $1^{\mathrm{a}}$ & $1.167^{\mathrm{c}}$ & $9.17^{\mathrm{a}}$ & $49.08^{\mathrm{a}}$ & $94.08^{\mathrm{a}}$ & $129.83^{\mathrm{a}}$ & $144.08^{\mathrm{a}}$ & $164^{\mathrm{a}}$ \\
3 & $1^{\mathrm{a}}$ & $2.75^{\mathrm{a}}$ & $10^{\mathrm{a}}$ & $39.92^{\mathrm{a}}$ & $97.33^{\mathrm{a}}$ & $128.83^{\mathrm{a}}$ & $147.83^{\mathrm{a}}$ & $155.33^{\mathrm{a}}$ \\
4 & $1^{\mathrm{a}}$ & $2^{\mathrm{bc}}$ & $12.83^{\mathrm{a}}$ & $43^{\mathrm{a}}$ & $85.17^{\mathrm{a}}$ & $76.83^{\mathrm{a}}$ & $93.75^{\mathrm{a}}$ & $108.42^{\mathrm{a}}$ \\
\hline
\end{tabular}

* Means within a column followed by the same small letter are not significantly different $(P \leq 0.05)$.

* Treat 1 is $100 \%$ sewage water, treat 2 is $60 \%$ sewage water, treat 3 is $30 \%$ sewage water, and treat 4 is control (Clean tap water). Dilution was done with clean tap water.

\section{Effect of Treatments Levels on Population Growth of Cowpea Aphid at Each Growth Stage}

When comparing treatments at 4 days interval, it has been found that treatment 1 had lower aphid number per plant than other treat- ments, where significance difference was observed. The trend observed at [Table-3] is that population levels of aphid per plant increased as sewage water was diluted. Similarly, we expected vice versa to be the case for the reasons as above of effect of $\mathrm{N}$ on aphid growth. It should be noted that inoculation of cowpea aphid on the cowpea plants was done at V5 plant growth stage. The population of aphid remained low from V 5 to V6 plant growth stage and a noticeable change started from V7 plant growth stage to the last day [Table-3].

Table 3- Effect of treatments levels to growth stage on population dynamics of cowpea aphid

\begin{tabular}{|lcccc|} 
Cowpea Growth & \multicolumn{4}{c}{ Water Treatments Means \pm SE } \\
Stage & 1 & 2 & 3 & 4 \\
\hline V5 & $1 \mathrm{a}$ & $1 \mathrm{a}$ & $1 \mathrm{a}$ & $1: 00 \mathrm{AM}$ \\
V6 & $0.672 \pm 12.55^{\mathrm{a}}$ & $1.00 \pm 12.55^{\mathrm{a}}$ & $1.8685 \pm 12.37^{\mathrm{a}}$ & $1.382 \pm 12.50^{\mathrm{a}}$ \\
V7 & $1.167 \pm 2.55^{\mathrm{a}}$ & $2.853 \pm 12.25^{\mathrm{a}}$ & $0.6266 \pm 12.71^{\mathrm{a}}$ & $1.065 \pm 12.55^{\mathrm{a}}$ \\
V8 & $9.0145 \pm 11.76^{\mathrm{a}}$ & $9.339 \pm 11.93^{\mathrm{a}}$ & $9.3611 \pm 11.77^{\mathrm{a}}$ & $11.964 \pm 11.79^{\mathrm{a}}$ \\
R1 & $32.427 \pm 28.33^{\mathrm{a}}$ & $17.393 \pm 38.85^{\mathrm{a}}$ & $21.907 \pm 28.34^{\mathrm{a}}$ & $57.333 \pm 32.19^{\mathrm{a}}$ \\
R2 & $66.05 \pm 11.27^{\mathrm{a}}$ & $83.300 \pm 11.38^{\mathrm{b}}$ & $79.22 \pm 11.29^{\mathrm{ab}}$ & $65.2634 \pm 11.29^{\mathrm{a}}$ \\
R3 & $85.271 \pm 22.58^{\mathrm{a}}$ & $81.149 \pm 22.42^{\mathrm{a}}$ & $78.95 \pm 25.79^{\mathrm{ab}}$ & $89.8784 \pm 21.29^{\mathrm{a}}$ \\
R4 & $105.83 \pm 15.48^{\mathrm{a}}$ & $128.73 \pm 13.79 \mathrm{a}$ & $131.92 \pm 14.70^{\mathrm{a}}$ & $82.1806 \pm 14.87 \mathrm{a}$ \\
R6 & $140.08 \pm 21.23^{\mathrm{a}}$ & $158.58 \pm 38.85^{\mathrm{a}}$ & $108.62 \pm 25.79^{\mathrm{a}}$ & $45.961 \pm 28.33^{\mathrm{b}}$ \\
R7 & $110.88 \pm 21.23^{\mathrm{a}}$ & $167.83 \pm 18.84 \mathrm{~b}$ & $164.85 \pm 18.32^{\mathrm{b}}$ & $94.528 \pm 22.39 \mathrm{a}$ \\
\hline
\end{tabular}

* Means within a column followed by the same small letter are not significantly different $(P \leq 0.05)$.

* Treatment 1 is $100 \%$ effluent water, treatment 2 is $75 \%$ effluent water, treatment 3 is $50 \%$ effluent water, treatment 4 is $25 \%$ effluent water and treatment 5 is the control which is 100\% tap water.

Table 4- Composition of effluent water from Glen Valley sewage

\begin{tabular}{|lcc|}
\multicolumn{1}{c}{} & ponds & \\
\hline Parameter & Symbol & Concentration $(\mathrm{mg} / \mathrm{l})$ \\
\hline Nitrate & $\mathrm{NO}^{-{ }^{-}}$ & $35.5 \pm 0.43$ \\
Potassium & $\mathrm{K}$ & 23.46 \\
Magnesium & $\mathrm{Mg}$ & 14.34 \\
Chloride & $\mathrm{Cl}$ & $671 \pm 2.09$ \\
Calcium & $\mathrm{Ca}$ & 33.07 \\
Total Dissolved Solids & $\mathrm{TDS}$ & 442.86 \\
\hline
\end{tabular}

Source: National Environmental Laboratory Building (Department of Waste Management and Pollution Control), Gaborone, Botswana.

The average population of cowpea aphids per plant from first day of observation to last day of observation for the treatments at each growth stage was found to be significantly different $\left(F_{3,1437}=36.52 ; P\right.$ $<0.0001$ ). During the plant growth stages from V1 to R4, the average aphid counts per plant among all treatments were observed to be not significantly different [Table-3]. Major differences in aphid numbers per plant were showed at plant reproductive stages R6 and R7. At plant growth stage R3 and R4 aphid population increased and this collided with cowpea plant having succulent pods and vining nodes [Table-3]. Fernandes, et al [26] found that higher aphid population feeding was distributed more on the pods and nodes than on the leaves mainly because of high nitrogen concentration.

Generally, this study has revealed that eventhough the nitrate content in the sewage water was at significant amounts, it did not influence or affect the population growth of aphids. In addition, it was also found from the sewage water analysis that the water had noticeable amounts of potassium (23.46 mg/l) [Table-4]. Potassium has been reported to negatively affect the population growth of 
insect. It has been reported to reduce population of aphids by reducing concentrations of free amino acids (Gash 2012). Therefore, it can be said that the presence of $\mathrm{N}$ does not always imply positive aphid growth especially when other elements are available at certain concentration levels such as potassium.

\section{Conclusion}

This study has shown that effluent water at all concentrations does not show any distinct and significant effect on cowpea aphid reproduction and population growth compared with clean tap water. Therefore, its use by farmers will not affect the population levels of aphids on cowpea crops.

\section{Acknowledgement}

The authors are thankful to Botswana College of Agriculture for allowing them to use their field to carry out the experiment.

Conflict of Interest : None declared.

\section{Reference}

[1] Emongor V.E., Ramolemana G.M., Machacha S., Khonga V.E., Marumo K. (2005) Journal of Applied Science, 5, 451-454.

[2] Department of Environment and Conservation (2004) Environmental Guidelines: Use of Effluent by Irrigation, Sydney, Australia.

[3] Mulla M.S., Mian L.S. and Gratz N.G. (1987) Journal of Agricultural Entomology, 4, 97-131.

[4] Machacha M., Obopile M., Tshegofatso A.B.N., Tiroesele B., Gwafila C. and Ramokapane M. (2012) International Journal of Tropical Insect Science, 32, 189-193.

[5] Dominic J., Udoh B.A. and Asequo N.U. (2005) Journal of Stored Products Research, 37, 216-217.

[6] Langyintuo A.S., Lowenberg-DeBoer J., Faye M., Lambert D., Ibro G., Moussa B., Kergna A., Kushwaha S., Musa S. and Ntoukam G. (2003) Field Crops Research, 82, 215-231.

[7] Jackai L.E.N. and Daoust R.A. (1986) Annual Review of Entomology, 31, 95-119.

[8] Youdeowei A. (1989) The Search for Sustainable Solutions to Crop Pest Problems in Africa, Cotonou (Benin), 31-50.

[9] Obopile M. (2006) African Plant Protection, 12, 111-115.

[10]Singh S.R. and Jackai L.E.N. (1985) Cowpea Research, Production and Utilization, 217-231.

[11]Ofuya T.I. (1997) Integrated Pest Management Review, 2, 199207.

[12]John S.S. and McConchie D.M. (1994) Australian Journal of Agricultural Research, 45, 160-171.

[13]Noma T., Gratton C., Garcia M.C., Brewer M.J., Mueller E.E., Wyckhuys K.G., Heimpel G.E. and O'nea M.E. (2010) Environmental Entomology, 39, 31-41.

[14]Dixon A.F.G. (1998) Aphid Ecology: An Optimization Approach, 2nd ed., Chapman and Hall, London.

[15]Awmack C.S. and Leather S.R. (2002) Annual Review of Entomology, 47, 817-844.

[16]Nevo E. and Coll M. (2001) Journal of Economic Entomology, 94, 27-32.

[17]Honek A. (1991) Journal of Plant Disease Protection, 98, 655660.
[18]Marwat G.N., Ahmad I. and Khatoon S. (1985) Sarhad Journal of Agriculture, 1, 223-229.

[19]Havlickova H. and Smetankova M. (1998) Rostlinna Vyroba, 44, 379-383.

[20]Myers S.W., Gratton C., Wolkowski R.P., Hogg D.B. and Wedberg J.L. (2005) Journal of Economic Entomology, 98, 113-120.

[21]Fehr W.R., Caviness C.E., Burmood D.T. and Pennington J.S. (1971) Crop Science, 11, 929-931.

[22]SAS Institute (2003) SAS Users Guide: Statistics, Cary, North Carolina.

[23]Karley A.J., Parker W.E., Pitchford J.W. and Douglas A.E. (2004) Ecological Entomology, 29, 383-388.

[24]de Valpine P. and Rosenheim J.A. (2008) Ecology, 89, 532541.

[25]Throop H.J., Hollandw E.A., Partonz W.J. and Keoughz C.A. (2004) Global Change Biology, 10, 1092-1105.

[26]Fernandes G.W., Coelho M.S. and Luttge U. (2010) Brazilian Journal of Biology, 70, 723-728.

[27]Gash A.J.F. (2012) Journal of Agronomy, 2, 1-13. 